\title{
Nilai Budaya dalam Novel Ulid Karya Mahmud Ikhwan Suatu Tinjauan Postmodernisme Jean Francois Lyotard
}

\author{
${ }^{1}$ Harmita Sari, ${ }^{2}$ Sumiati Putri Natalia, ${ }^{3}$ Wahyuniar, ${ }^{4}$ A. Nurhayati \\ ${ }^{1}$ Fakultas Ekonomi dan Bisnis, Universitas Muhammadiyah Palopo, Jl. \\ Jenderal Sudirman KM.03 Binturu \\ ${ }^{2}$ Institut Agama Kristen Negeri Toraja, Jl. Poros Makale-Makassar Km. 11,5 \\ Mengkendek Tana Toraja \\ 3Universitas Musamus, Jl Kamizaun Merauke \\ ${ }^{4}$ Fakultas Keguruan dan Ilmu Pendidikan, Universitas Muhammadiyah \\ Palopo, Jl. Jenderal Sudirman KM.03 Binturu \\ surel: harmitasari93@gmail.com
}

\begin{abstract}
Abstrak
Penelitian ini bertujuan untuk mendeskripsikan aspek-aspek budaya postmodernisme yang terdapat dalam novel Ulid karya Mahfud Ikhwan yang terdiri dari; ekletisisme, parodi, pastiche, ironi, dan camp. Jenis penelitian ini adalah penelitian kualitatif yang bersifat deskriptif. Data dalam penelitian ini berupa kata, frasa, klausa atau kalimat yang berwujud ekletisisme, parodi, pastiche, ironi, dan camp. Sumber data dalam penelitian ini adalah sebuah novel yang berjudul Ulid Karya Mahfud Ikhwan. Teknik pengumpulan data yang digunakan dalam penelitian ini adalah teknik baca, teknik simak, dan teknik catat dengan teknik analisis data yaitu mengidentifikasi, mengklasifikasi, mendeskripsikan dan menginterpretasikan. Hasil penelitian dalam novel Ulid karya Mahfud Ikhwan menunjukkan bahwa terdapat berbagai situasi yang menggambarkan perilaku postmodernisme yang lebih didominasi oleh sifat ironi yang ditemukan dalam berbagai situasi seperti bencana alam, perekonomian dan hal-hal yang bertentangan dengan perasaan. Aspek selanjutnya adalah prilaku Camp yang digambarkan dalam bentuk pengelabuan penampilan, sikap, benda dan sifat. Pastiche diungkapkan melalui situasi yang berhubungan dengan perilaku tokoh, harapan di masa lalu, serta informasi mengenai tokoh pada
\end{abstract}


Jurnal Onoma: Pendidikan, Bahasa dan Sastra PBSI FKIP Universitas Cokroaminoto Palopo Volume 7 Nomor 1 Tahun 2021
ISSN 2443-3667 (print)

ISSN 2715-4564 (online)

masa lalu Ekletisisme yang digambarkan dalam bentuk perpaduan benda, bahasa dan makanan. Aspek parodi diungkapkan dalam bentuk ungkapan perasaan puas, tidak senang, dan tidak nyaman. Berdasarkan hasil penelitian dalam novel Ulid karya Mahfud Ikhwan dapat disimpulkan bahwa masyarakat postmodern dapat diidentifikasi dari aktivitas atau tindakan yang digambarkan oleh tokoh dalam menyikapi sebuah peristiwa yang berhubungan dengan zamannya.

Kata Kunci: postmodernisme, ekletisisme, parodi, pastiche, ironi, camp

\section{Pendahuluan}

Seiring perkembangan zaman, maka berkembang pula istilah-istilah dan paradigma baru sebagai pengganti istilah yang telah ada dalam masyarakat, juga terjadi pembaruan-pembaruan yang terjadi dalam perkembangan karya sastra yang kaya akan nilai budaya. Masyarakat dan budaya adalah suatu sistem yang tidak dapat dipisahkan satu sama lain karena tidak ada budaya yang tidak tumbuh dan berkembang dari suatu masyarakat (Sari \& Maming, 2019). Nilai budaya yaitu mengajak semua masyarakat agar selalu menjaga dan mengembangkan adat yang mengandung pesan moral yang perlu diterapkan di kehidupan sehari-hari (Sari, dkk. 2020).

Perkembangan pemikiran dari masa ke masa terus mengalami perubahan dalam berbagai hal, tentunya hal tersebut tidak lepas dari keinginan manusia yang menginginkan sebuah perubahan karena bertambahnya persoalan dan juga kebutuhan dalam kehidupan manusia. Berdasarkan permasalahan ini, acuan penelitian mengenai karya sastra merujuk dalam Undang-Undang Nomor 57 tahun 2014 mengenai pengembangan, pembinaan, dan perlindungan bahasa dan sastra, serta peningkatan fungsi bahasa Indonesia pada pasal 13 ayat (2) dalam butir pertama menyatakan bahwa "Pengembangan Sastra Indonesia dilakukan melalui penelitian kesastran Indonesia". Hal tersebut yang mendasari perlunya dilakukan penelitian dan pengkajian mengenai karya sastra dengan mempertimbangkan berbagai perspektif teori guna mengetahui bentuk dan isi dari karya sastra tersebut.

Kritik sastra dapat bertujuan sebagai pembuktian apakah karya sastra tersebut benar-benar dapat digolongkan sebagai karya sastra yang baik ataupun karya sastra yang buruk. Kemudian dalam penelitian ini sumber data yang akan dipakai adalah novel Ulid karya Mahfud Ikhwan, novel tersebut tergolong dalam karya sastra yang masih diragukan baik buruknya karena belum pernah diteliti. Menurut Rengganis (2017) Karya sastra hadir dalam masyarakat melalui bahasa dalam wujud kata, frasa, kalimat maupun paragraf yang merupakan perwakilan dari sang penulis untuk menyampaikan keinginan, pemikiran, pendapat atau gagasan pada pembaca (masyarakat). Pembagian fiksi dapat berdasarkan isi maupun bentuknya. Menurut Lubis (2014) berdasarkan isinya, fiksi dapat diklasifikasikan atas romantik, realisme, sosialis realisme, naturalisme, ekspresionisme dan simbolisme.

Novel sebagai suatu karya fiksi menawarkan suatu dunia yaitu berisi suatu model yang diidealkan, dunia imajiner, yang dibangun melalui sistem intrinsiknya, seperti peristiwa, plot, tokoh (penokohan), latar, sudut pandang dan nilai-nilai yang sifatnya imajiner (Nurgiyantoro, 2007). Kata novel berasal dari bahasa Latin novellus yang dibentuk dari kata novus yang berarti baru atau new dalam bahasa Inggris. Dikatakan baru karena bentuk novel adalah bentuk karya sastra yang datang kemudian dari 
Jurnal Onoma: Pendidikan, Bahasa dan Sastra PBSI FKIP Universitas Cokroaminoto Palopo Volume 7 Nomor 1 Tahun 2021
ISSN 2443-3667 (print)

ISSN 2715-4564 (online)

bentuk karya sastra lainnya, yaitu puisi dan drama (Priyatni, 2012: 124). Awalan "post" dalam istilah "postmodernisme" memberikan indikasi bahwa paham ini membahas ide tentang kehidupan sosial di luar kondisi modernitas yang diteorikan oleh sebagian para filsof barat seperti Weber, Marx, Comte (Gudono; 2009:21). Kemunculan paham postmodernisme oleh banyak orang dianggap sebagai respons atas kegagalan teori-teori modernitas sebelumnya dalam menjelaskan perubahan luar biasa dalam peradaban saat ini. Lyotard mengartikan post berarti pemutusan hubungan pemikiran total dari segala pola kemodernan. David Griffin mengartikannya sekedar koreksi atas aspek-aspek tertentu saja dari kemodernan. Sementara Habermas, satu tahap dari proyek modernisme yang memang belum selesai (Maksum; 2008: 306). Beberapa aspek sentral yang diasosiasikan dengan postmodernisme dalam seni (Jean-Francois Lyotard dalam Sarup, 2007: 226) antara lain: ekskletisisme, parodi, pastiche, ironi, dan camp.

Novel Ulid karya Mahfud Ikhwan ini merupakan novel yang memiliki gaya penceritaan yang menarik dan detail dengan karakteristik isi cerita yang mengemukakan kebudayaan yang masih sangat lekat dengan kehidupan masyarakat dalam novel tersebut. Selain itu, dalam novel menggambarkan alur pada tokoh utama memiliki rasa ingin tahu yang tinggi terhadap hal baru yang didengarnya kemudian menciptakan imajinasi dan menggambarkannya dalam pikiran mereka. Isi cerita menggambarkan manusia dengan gaya hidup yang ditonjolkan sebagai gaya hidup postmodern, yaitu manusia yang mengalami perubahan budaya atau cara pikir yang terjadi akibat perkembangan zaman.

Novel Ulid karya Mahfud Ikhwan memiliki keunggulan dibandingkan dengan novel-novel lainnya, yaitu pada penggambaran perilaku-perilaku manusia yang mencerminkan perilaku manusia postmodernisme serta terdapat bentuk-bentuk kebudayaan yang bersifat modern. Selanjutnya, sepanjang pengetahuan peneliti novel Ulid karya Mahfud Ikhwan ini memang belum pernah dikaji dengan teori apapun, terkhusus mengenai teori postmodernisme Jean Francois Lyotard. Menurut peneliti fenomena kehidupan masyarakat postmodernisme yang lebih ditonjolkan dalam novel Ulid karya Mahfud Ikhwan ini sehingga novel tersebut layak dikaji dengan menggunakan postmodernisme yang kemudian penelitian ini akan difokuskan pada kajian aspek budaya postmodernisme.

Penelitian yang dilakukan Fitriana (2017) dalam bentuk jurnal yang diberi judul Identitas budaya dalam novel kembar keempat karya Sekar Ayu Asmara: Kajian Postmodernisme. Penelitian ini menunjukkan bahwa novel kembar keempat terdapat identitas budaya dari segi postmodernisme yang berupa agama sebagai pembebas dan pembaharu, pengelabuan dan penopengan sebagai pembentukan kesan serta adopsi budaya sebagai ekspresi kebudayaan yang tidak terikat ruang. Penelitian berbeda kemudian dilakukan oleh Prihantono (2018) juga dalam bentuk jurnal penelitian dengan judul Analisis stilistika Seno Gumira Ajidarma dalam cerpen rembulan dalam capucino: kajian postmodernisme Jean Francois Lyotard Penelitian ini menemukan kepostmodernan gaya SGA yang melibatkan gaya sekurangkurangnya tujuh gaya postmodernisme yakni fragmentasi, permainan bahasa yang sublim, pastiche, parodi, kitsch, camp, dan skizofrenia. 
Jurnal Onoma: Pendidikan, Bahasa dan Sastra PBSI FKIP Universitas Cokroaminoto Palopo Volume 7 Nomor 1 Tahun 2021
ISSN 2443-3667 (print)

ISSN 2715-4564 (online)

Berdasarkan uraian di atas, disimpulkan bahwa penelitian yang dilakukan oleh Prihantono, tidak membahas secara tuntas mengenai aspek budaya dari postmodernisme Jean Francois Lyotard. Penelitian yang dilakukan Fitriana yang membahas mengenai posmodernisme Jean Francois namun tidak memasuki ranah aspek kebudayaan, yang mengungkapkan kebudayaan menggunakan postmodernisme secara umum. Berdasarkan data tersebut, peneliti berusaha mengungkapkan aspek-aspek budaya secara lebih lengkap dengan menggunakan postmodernisme Jean Francois Lyotard, maka ditarik judul: Aspek Budaya dalam novel Ulid karya Mahfud Ikhwan, suatu tinjauan Postmodernisme Jean Francois Lyotard.

\section{Metode}

Jenis penelitian yang digunakan adalah penelitian kualitatif yang bersifat deskriptif. Dalam hal ini, penelitian dilakukan untuk mencapai tujuan yang diinginkan dengan memberikan deskripsi atas data-data yang dipilih dalam wujud kata dan menafsirkan data sesuai dengan teori postmodernisme menurut Jean Francois Lyotard. Fokus penelitian ini adalah aspek budaya postmodernisme, meliputi: ekletisisme, pastiche, parodi, dan ironi, yang terdapat dalam novel Ulid Karya Mahfud Ikhwan. Data dalam penelitian ini berupa kata, frasa, klausa atau kalimat yang berwujud ekletisisme, pastiche, parodi, dan ironi yang terdapat dalam novel Ulid karya Mahfud Ikhwan. Sumber data dalam penelitian ini yaitu berupa novel yang berjudul Ulid karya Mahfud Ikhwan diterbitkan oleh Pustaka Ifada, Yogyakarta Februari 2016, dengan tebal buku 538 halaman.

Teknik pengumpulan data dalam penelitian ini dilakukan dengan langkahlangkah: (1) Teknik baca dilakukan dengan membaca berulang novel tersebut dan mengamati kata, frasa, klausa, teks-teks atau kalimat yang menunjukkan wujud aspek-aspek budaya dalam novel Ulid karya Mahfud Ikhwan; (2) Teknik simak dilakukan dengan mempelajari kembali novel tersebut dengan teliti sehingga bisa menghasilkan data yang berupa kata, frasa, klausa atau kalimat yang sesuai. (3) Teknik catat ini dilakukan dengan mencatat data yang telah diidentifikasi sebelumnya untuk kemudian diolah dalam penelitian. Teknik analisis data dalam penelitian ini berupa deskriptif kualitatif dengan kajian Postmodernisme. Analisis data yang digunakan mengikuti langkah-langkah: (1) Tahap identifikasi; (2) Tahap mengklasifikasi dan menganalisis; (3) Tahap deskripsi; dan (4) Tahap interpretasi.

\section{Hasil dan Pembahasan}

Penelitian ini menganalisis novel Ulid karya Mahfud Ikhwan menggunakan teori Jean Francois Lyotard. Ditemukan beberapa kalimat dalam novel, diantaranya terdapat 111 data yang terbagi atas kata, frasa, klausa dan kalimat yang diwakili oleh 30 data yang diuraikan berdasarkan bagian-bagian aspek yaitu ekletisisme, parodi, pastiche, dan ironi. Ditemukan 3 data yang menunjukkan bentuk ekletisisme yaitu aktivitas mencampurkan atau memadukan kebudayaan lokal dan kebudayaan luar, ditemukan 7 data yang menunjukkan bentuk parodi yaitu prilaku yang mendramatisasi suatu keadaan kemudian yang pengungkapannya mengandung humor, ditemukan 4 data yang menunjukkan bentuk pastiche yaitu dapat dilihat dari 
Jurnal Onoma: Pendidikan, Bahasa dan Sastra PBSI FKIP Universitas Cokroaminoto Palopo Volume 7 Nomor 1 Tahun 2021
ISSN 2443-3667 (print)

ISSN 2715-4564 (online)

teks-teks yang menunjukkan masa lalu kemudian diangkat kembali dengan versi yang berbeda, ditemukan 3 data yang menunjukkan bentuk ironi yang dapat ditandai dengan kejadian-kejadian yang bertentangan dengan harapan akan tetapi telah menjadi kenyataan, ditemukan 13 data yang menunjukkan keberadaan bentuk camp yang dapat ditandai dengan adanya pengelabuan identitas terhadap sesuatu untuk menciptakan sebuah pencitraan sesuatu hal. Hal-hal tersebut kemudian diuraikan sebagai berikut:

\section{Bentuk Ekletisisme dalam Novel Ulid karya Mahfud Ikhwan}

Kegemaran memadukan dua kebudayaan yaitu kebudayaan dari luar dan kebudayaan dari dalam negeri dapat terlihat jelas digambarkan oleh tokoh dalam novel Ulid karya Mahfud Ikhwan. Penggunaan benda, bahasa, atau aktivitas luar negeri menjadi salah satu ciri utama dari aktivitas ekletisisme. Hal ini dapat dilihat dari kutipan berikut:

(1) Setelah keluar dari toko elektronik dengan menenteng sebuah kotak warna biru

bertulis national, bapak dan anak itu masuk toko mebel (Ikhwan, 2016: 63).

Kutipan tersebut menjelaskan adanya penggunaan benda yang bukan berasal dari negara sendiri melainkan dari luar negeri. Benda yang dimaksud adalah radio national, sedangkan benda tersebut dari luar negeri yaitu buatan Jepang. Meskipun benda tersebut dibeli di dalam negeri akan tetapi benda tersebut tetap berasal dari luar negeri. Aktivitas menggunakan barang buatan luar negeri ini merupakan salah satu ciri-ciri dari bentuk akitivitas ekletisisme. Penggunaan bahasa asing juga dapat dikategorikan sebagai bentuk ekletisisme, seperti dalam kutipan berikut:

(2) Jika berhasil mengelabui migresen di Malaka, seorang teman kusen akan menjemput dan membawa rombongan ke pinggir serembah (Ikhwan, 2016:142).

Kutipan pada data (2) menjelaskan adanya bentuk pencampuran kebudayaan dalam kategori bahasa, kata yang dimaksud sebagaimana yang telah di cetak miring yaitu migresen yang dalam bahasa Indonesia berarti imigrasi. Bahasa yang dipakai dalam kata tersebut adalah bahasa dari Negara Malaysia yang dicampuradukkan dengan bahasa Indonesia. Dalam hal ini sangat jelas bahwa telah dilakukan pencampuran dua kebudayaan dalam bentuk bahasa. Hal ini menandakan bahwa kebudayaan lokal dan kebudayaan asing telah tumbuh secara berdampingan seiring dengan semakin luasnya pergaulan. Aktivitas sehari-hari juga tidak terlepas dari kegiatan ekletisisme, seperti dalam kutipan berikut:

(3) Ulid bangun dengan perasaan gundah dan tetap seperti beberapa hari belakangan, ia tak menemukan bapaknya di sampingnya atau diberanda sedang merokok, atau sedang coba cari gelombang radio BBC London pada band SW sebagaimana hampir setiap pagi dilakukan Tarmidi (Ikhwan, 2016:182).

Pada data (3) dapat dinyatakan bahwa terdapat pengadopsian prilaku seharihari yang dipengaruhi oleh kebudayaan asing, dapat dilihat dari tokoh yang sedang mendengarkan siaran gelombang BBC London pada band SW yang merupakan layanan stasiun radio yang berasal dari London, Inggris. Hal ini membuktikan adanya pengadopsian kebiasaan yang dilakukan oleh masyarakat lokal sebagaimana masyarakat asing. Tidak hanya kebiasaan sehari-hari yang dijadikan ciri dari ekletisisme tetapi paling dominan adalah penggunaan benda dari Negara luar. 
Jurnal Onoma: Pendidikan, Bahasa dan Sastra PBSI FKIP Universitas Cokroaminoto Palopo Volume 7 Nomor 1 Tahun 2021
ISSN 2443-3667 (print)

ISSN 2715-4564 (online)

\section{Bentuk Parodi dalam Novel Ulid karya Mahfud Ikhwan}

Parodi ini dapat dicermati melalui suatu bentuk dialog, cerita berupa teks atau verbal yang mengekspresikan perasaan puas, tidak senang, tidak nyaman berkenaan dengan intensitas gaya seperti sindiran atau humor yang dibangun berdasarkan perasaan. Parodi terbentuk pula dengan rasa takut yang diciptakan dengan melebihlebihkan suatu kejadian demi menyakinkan lawan bicara untuk takut dengan apa yang disampailkan tetapi dengan gaya yang memiliki humor, seperti dalam kutipan:

(4) "Nanti digigit sinder loh" Si emak memasang wajah yang menakutkan, giginya diseringaikan dengan gerakan hendak ingin mencaplok. Ia ingin mengingatkan kepada anaknya betapa menakutkan yang disebut barusan (Ikhwan, 2016:05).

Pada data (4) dalam kalimat "nanti digigit sinder loh" diungkapkan suatu kalimat yang diharapkan memberi rasa takut kepada tokoh lainnya yaitu dengan menggunakan ungkapan yang berlebih-lebihan. Ungkapan ini dianggap sebagai humor belaka karena sinder sebenarnya hanyalah orang biasa yang tidak mungkin memakan manusia. Parodi juga terbentuk dari sifat mendramatisasi kejadian yang dibangun dari perasaan manusia, sindiran-sindiran dalam parodi digunakan sebagian orang untuk menjelaskan suatu hal yang tidak dihiraukan oleh orang kebanyakan. Hal ini dapat dicermati dari kutipan:

(5) "Kalau diulangi bukan hanya sulit kencing, anumu bisa bengkak lalu melepuh lalu jadi borok, lalu putus" Tarmidi menasehati anaknya dengan muka yang amat bersungguh-sungguh (Ikhwan, 2016:37).

Pada data (5) pada kalimat "Kalau diulangi bukan hanya sulit kencing, anumu bisa bengkak lalu melepuh lalu jadi borok, lalu putus" dapat dicermati bahwa pemberian nasehat oleh tokoh kepada tokoh lainnya mengandung sifat mendramatisasi dari keadaan yang sebenarnya. Tokoh memberi nasihat bahwa anaknya itu tidak boleh kencing disembarang tempat dengan dalih bahwa jika ia tetap melakukan hal tersebut maka "anunya" akan melepuh kemudian putus. Pemberian nasihat kepada anak kecil memang seharusnya dilakukan dengan diselingi humorhumor agar anak tidak merasa dikerasi. Pendramatisasian keadaanseperti ini dengan diselingi humor menjadi salah satu ciri bentuk parodi. Adapun bentuk keluhan yang mengungkapan sesuatu keadaan dengan melebih-lebihkan dari keadaan sebenarnya juga dapat dicermati dari kutipan berikut:

(6) Kalau untuk aku, sudah cukuplah kata kehujanan batu. Lihat bukit itu. Batu dimanamana. Apakah itu bukan kehujanan batu? Aku sekarang mau kehujanan emas (Ikhwan, 2016:137).

Pada data (6) kalimat yang menggambarkan keluh kesah yang disampaikan secara berlebihan untuk mengungkapkan suatu keadaan yang sebenarnya. Seperti dalam kata "kehujanan batu" yang pada dasarnya ungkapan tersebut adalah ungkapan yang digunakan untuk menggambarkan suatu keadaan daerah yang memiliki banyak batu dalam wilayahnya. Kemudian disampaikan pula ungkapan yang kemudian diharapkan oleh masyarakat yaitu "kehujanan emas" tentu saja ini bukan sebenarnya karena tidak mungkin ada hujan emas, makna sebenarnya adalah dilimpahi rezeki. Bukan saja ungkapan yang berlebihan disampaikan dalam segi keadaan geografis, akan tetapi pada perasaan tidak senang yang disampaikan secara berlebihan, contoh dalam data berikut: 
Jurnal Onoma: Pendidikan, Bahasa dan Sastra PBSI FKIP Universitas Cokroaminoto Palopo Volume 7 Nomor 1 Tahun 2021
ISSN 2443-3667 (print)

ISSN 2715-4564 (online)

(7) "Kamu bisa mual-mual kena fisika". "banyak sekali nama-nama aneh yang harus kau hafal dalam biologi, bisa kriting lidahmu". "Bahasa Inggris itu lucunya bukan main, tapi awas jangan sampai kamu tertawa . kena marah pak Yan pastii" (Ikhwan, 2016:219).

Kutipan (7) kembali diterangkan sifat dari parodi yaitu mengungkapkan rasa tidak senang dengan melebih-lebihkan suatu keadaan. Dalam kalimat "kamu bisa mual-mual kena fisika". "Banyak sekali nama-nama aneh yang harus kau hafal dalam biologi, bisa kriting lidahmu". Tokoh menyatakan rasa tidak senangnya terhadap palajaran sekolahnya melalui verbal. Kemudian ketidaksukaannya tersebut diungkapkan dengan melebih-lebihkan akibat yang didapat dari pelajaran tersebut. Hal ini dapat dilihat dari kalimat fisika membuat mual-mual dan mengahafal namanama aneh dalam biologi bisa membuat lidah jadi kriting. Hal yang sama juga dapat dicermati dari kutipan berikut:

(8) Cita-cita itu makanan jenis apa Lid? Aneh-aneh saja kamu. Yamin menjawab dengan cengar-cengir (Ikhwan, 2016:391).

Data (8) ketidaktahuannya terhadap suatu ungkapan membuat tokoh mendefinisikan sendiri mengenai sesuatu hal tersebut. Seperti dalam kalimat "Citacita itu makanan jenis apa Lid? Ia mengungkapkan seolah-olah cita-cita adalah sejenis makanan, ketika ditanya mengenai cita-cita apa yang kira-kira harus menjadi tujuan Ulid. Tentu saja hal ini berbeda dari makna sebenarnya mengenai cita-cita. Penggunaan ungkapan yang menggambarkan sebuah bentuk yang berbeda dengan keadaan sebenarnya dalam hal ini perasaan yang muncul kadangkala disampaikan dengan berlebihan agar lawan bicara lebih bersimpati dengan apa yang kita sampaikan, seperti dalam data berikut:

(9) "ya, daripada payah-payah harus pulang kerumah tumpang Lid. Sudah bayar banyak polis pula" Pi'I berkata dengan teratawa tentu saja. "Daripada digigiti kutu busuk di kongsi, lebih baik digigiti bu Jaenah, yak kan I?" "sudah hangat diperaduan, makan dikantin dikasih percuma pula." Nurdin menyahut juga dengan tawa (Ikhwan, 2016:451).

Data (9) dalam kalimat "daripada digigiti kutu busuk dikongsi, lebih baik digigiti bu Jaenah" merupakan ungkapan perasaan yang menunjukkan adanya perbandingan. Perbandingan yang disajikan tidak benar-benar merupakan sebuah perbandingan yang sepadan, malah diungkapkan dengan kalimat humor. Kalimat ini sebenarnya mengungkapkan sebuah keadaan baik dan keadaan buruk, yang dalam hal ini seolah-olah tidak ada pilihan lain selain apa yang telah dipilihnya yaitu menikah dengan bu Jaenah. Dalam keadaan ini terlihat sebuah perasaan pasrah yang dimiliki oleh tokoh. Adapun kalimat lain yang menggambarkan adanya prilaku parodi dalam novel dapat dilihat dari data berikut:

(10) “Eh sebentar. Tidakkah disana banyak genderuwonya, Din? Macam mana tuh?” Pi'I masih mengajukan hal-hal yang memberatkan. "kalau selama ini aku berkawan dengan kau saja tak takut, kenapa aku mesti taku genderuwo? Seperti anak nyonya mana saja kau ini? Bukankah waktu kecil itu tempat kau berkeliaran? Ah rupanya tiga tahun di Malaysia kau dah tertular nyali kecil orang sana!” kali ini Nurdin yang jengkel (Ikhwan, 2016:493).

Data (10) dalam kalimat "kalau selama ini aku berkawan dengan kau saja tak takut, kenapa aku mesti takut genderuwo? Merupakan ungkapan yang bernada mengejek, ketika tokoh membandingkan tokoh lainnya dengan genderuwo yang 
Jurnal Onoma: Pendidikan, Bahasa dan Sastra PBSI FKIP Universitas Cokroaminoto Palopo Volume 7 Nomor 1 Tahun 2021
ISSN 2443-3667 (print)

ISSN 2715-4564 (online)

merupakan sebuah makhluk yang terkenal seram. Secara tidak langsung pengungkapan itu menjelaskan bahwa temannya lebih seram dari genderuwo. Tentu saja ungkapan itu tidaklah diungkapkan secara serius akan tetapi hanya sebuah ejekan yang lebih kepada membuat orang tertawa. Ungkapan-ungkapan berlebihan dari kenyataan aslinya untuk mengungkapkan perasaan bahagia atau sedih, puas atau tidak puas, nyaman atau tidak nyaman atau perasaan apapun yang kemudian diungkapkan secara berlebih-lebihan sehingga terdengar seperti sebuah lelucon merupakan suatu aktivitas parodi.

\section{Bentuk Pastiche dalam Novel Ulid karya Mahfud Ikhwan}

Tokoh dalam novel Ulid karya Mahfud Ikhwan digambarkan sebagai tokoh yang melakukan aktivitas peniruan terhadap sesuatu atau sejenis pengimitasian terhadap sesuatu yang dilihatnya. Seperti dalam kutipan:

(11)Si kecil melonjak gembira, meskipun tahu pasti ia akan dipaksa mengimbangi langkah-langkah besar orang dewasa. Tak apa. Ia melangkah mengikuti kedua orang tuanya dengan ceria, sebentar kemudian, ia harus berlari-lari kecil mengikuti kaki bapak emaknya yang terburu. Nafasnya juga ketika ia tertinggal agak jauh dari langkah bapak emaknya, ia menyadari sandal jepit kebesaran yang dipakaiannya menghambat langkahnya. Sandal itu kemudian berpindah ke telapak tangan (Ikhwan, 2016:8).

Pada data (11) tokoh Ulid melakukan aktivitas menirukan prilaku seseorang terlihat pada kalimat "Si kecil melonjak gembira, meskipun tahu pasti ia akan dipaksa mengimbangi langkah-langkah besar orang dewasa. Tak apa, tak apa tekadnya. Ia melangkah mengikuti kedua orang tuanya dengan ceria, sebentar kemudian, ia harus berlari-lari kecil mengikuti kaki bapak emaknya yang terburu" dalam kalimat tersebut dijelaskan bahwa kaki kecilnya harus menirukan langkah-langkah besar ayahnya agar tidak tertinggal dalam perjalanan tersebut. Akhirnya meskipun kadang ia harus berlari kecil untuk mengimbangi langkah-langkah ayahnya. Memiliki angan-angan atau bermimpi terjadinya sesuatu hal yang baik di masa depan juga merupakan suatu bentuk pastiche, seperti dalam kutipan:

(12) Si kecil tampak malas beranjak, meski itu hasil karya bapaknya. Ia merasa ia telah memiliki jubung yang siap dibakar. Ia tampak terpesona ketika melihat jubung yang mungil itu tak berbeda dengan jubung raksasa yang membukit di sampingnya. Hanya miliknya jauh lebih kecil. Itu tentu saja karena ia masih kecil, kalau besar nanti ia pasti akan membakar jubung yang sebesar itu. Mungkin bahkan lebih besar. Terbayang, besok pagi ia akan membakar jubung itu sendiri. Betapa perkasanya menjadi pembakar gamping (Ikhwan, 2016:27).

Pada data (17) dalam kalimat "Hanya miliknya jauh lebih kecil. Itu tentu saja karena ia masih kecil, kalau besar nanti ia pasti akan membakar jubung yang sebesar itu. Mungkin bahkan lebih besar." terlihat tokoh Ulid mengutarakan angan-angan yang ia harapkan ketika beranjak dewasa nanti yaitu memiliki jubung yang lebih besar dari apa yang dibuat oleh bapaknya. Memiliki angan-angan untuk lebih baik di masa depan merupakan suatu bentuk pastiche. Gambaran aktivitas yang dialami oleh tokoh dalam teks pastiche dikaitkan dengan peristiwa di masa lalu kemudian diapresiasi pada masa sekarang. Hal ini digambarkan dalam kutipan:

(13)Sehabis makan Tarmidi terpakasa menuruti permintaan anaknya. Jubung mungil itu sebentar kemudian ikut-ikut mengepul. Si kecil begitu bersemangat. Asap yang 
Jurnal Onoma: Pendidikan, Bahasa dan Sastra PBSI FKIP Universitas Cokroaminoto Palopo Volume 7 Nomor 1 Tahun 2021
ISSN 2443-3667 (print)

ISSN 2715-4564 (online)

mengepul dari jubung kecilnya seakan nyala lilin ulang tahun bocah yang begitu menggirangkan. Ia melocat-loncat, berteriak-teriak, membicarakan semua hal yang sebenarnya telah lama diamati sejak ia mulai melihat (Ikhwan, 2016:29).

Pada data (13) dalam kalimat "Asap yang mengepul dari jubung kecilnya seakan nyala lilin ulang tahun bocah yang begitu menggirangkan. Ia melocat-loncat, berteriak-teriak, membicarakan semua hal yang sebenarnya telah lama diamati sejak ia mulai melihat" gambaran aktivitas tersebut mengemukakan bahwa adanya bentuk pengungkapan dengan memetaforakan sesuatu yang terjadi sebenarnya dengan aktivitas lainnya yaitu saat asap mengepul dari jubung disamakan seperti nyala lilin ulang tahun bocah .

Kemudian pada kalimat "Ia melocat-loncat, berteriak-teriak, membicarakan semua hal yang sebenarnya telah lama diamati sejak ia mulai melihat" mengemukakan sebuah pengungkapan tentang sebuah peristiwa yang telah lama berlalu dan selalu ia perhatikan kemudian pada hari itu hal tersebut terjadi lagi meskipun dengan versi yang agak berbeda. Hal inipun dapat terlihat dalam data berikut:

(14)Penantian yang panjang juga membuat panen bengkuang menjadi senikmat buka puasa dihari pertama. Bengkuang merupakan tanaman yang panennya paling lama, setelah jagung dan padi asli Lerok mulai menghilang. Dissamping itu, bagaimana kamu tidak menantikannya jika kamu merasa bahwa kamu menjadi bagian sangat penting dari empat sampai lima bulan penantian itu? Tak seperti membakar gamping, siapapun bisa menanam bengkuang (Ikhwan, 2016:40).

Pada data (14) ditemukan pula ciri-ciri dari pastiche yaitu mengungkapkan sesuatu hal dengan sesuatu hal yang baru. Misalnya dalam kalimat "Penantian yang panjang juga membuat panen bengkuang menjadi senikmat buka puasa dihari pertama", dalam kalimat itu diungkapkan sebuah perasaan nikmat terhadap sesuatu hal yaitu panen bengkuang diibaratkan seperti buka puasa pertama, aktivitas tersebut mencerminkan adanya keterkaitan tentang hal-hal yang pernah dilakukan di masa lalu dalam pengungkapan perasaan kenikmatan suatu hal. Teks pastiche juga dapat berupa memberikan pengetahuan kepada pembaca berkenaan dengan peristiwa yang pernah terjadi, seperti dalam kutipan berikut:

\section{Bentuk Ironi dalam Novel ULid karya Mahfud Ikhwan}

Aktivitas dalam novel Ulid karya Mahfud Ikhwan yang menjadi ciri dari prilaku postmodernisme yaitu ironi atau suatu kejadian yang bertentangan dengan harapan akan tetapi telah menjadi sebuah suratan takdir, contoh dalam kutipan:

(15)Sudah tersiar kabar, Sinder petugas kehutanan diatas mantri telah mengambil Dolah dan Kastalim, teman-teman Tarmidi sesama pembakar gamping. Tarmidi tentu tak mau ikut-ikutan diangkut. Diangkut sinder dalah bencana besar. Ia tak mau peristiwa tujuh bulan lalu terulang kembali. Sehari digiring ke loji, ditanyai di polsek sehari lagi untuk kemudian pulang dengan tebusan sepuluh ribu. Sepuluh ribu jumlah yang hanya bisa didapat dari bekerja sebulan penuh itupun kalau sedang baik nasib (Ikhwan, 2016:04).

Pada data (15) digambarkan bahwa pada tujuh bulan lalu telah terjadi sebuah peristiwa yang bertentangan dengan harapan akan tetapi telah menjadi sebuah suratan takdir pada tokoh. Dijelaskan bahwa Tarmidi ayah dari Ulid pernah diangkut oleh sinder yaitu polisi yang mengawasi kehutanan, kemudian di giring ke loji dan kemudian pulang dengan harus membayar uang tebusan sebanyak sepuluh ribu 
Jurnal Onoma: Pendidikan, Bahasa dan Sastra PBSI FKIP Universitas Cokroaminoto Palopo Volume 7 Nomor 1 Tahun 2021
ISSN 2443-3667 (print)

ISSN 2715-4564 (online)

rupiah yang dikala itu merupakan jumlah yang banyak. Hal tersebut bertentangan dengan harapan tokoh yang tentu saja ingin bekerja dengan aman tanpa dihantui dengan rasa takut akan tertangkap oleh polisi. Kejadian tersebut sudah dianggap sebagai bencana besar yang pernah dialami oleh tokoh. Adapun contoh lain seperti dalam kutipan:

(16) Lerok memang agak aneh. Meski dikurung dengan perbukitan hijau yang begitu luas dan hutan yang hamper-hampir tak diketahui batasnya, persawahan mereka tak pernah cukup air. Air hanya ada di sumur-sumur batu di bawah bukit-bukit jauh diatas bentangan sawah mereka. Karena sawah hanya becek tak lebih dari lima bulan, bukitpun di gangsir, hutanpun di tebang, keduanya kemudian dipertemukan di rongga jubung. Lalu, lahirlah gamping. Namun jangan pernah membayangkan secara berlebihan tentang sebuah kawasan industry kapur, hanya jubung-jubung saja, kira-kira 20-an buah, tidak lebih dari itu (Ikhwan, 2016:18).

Pada data tersebut digambarkan adanya kesenjangan antara harapan dan kenyataan yang dialami oleh masyarakat yang bermukim di daerah tersebut. Keadaan geografis yang dikelilingi perbukitan yang luas serta hutan-hutan yang juga begitu luas harusnya menyimpan banyak sekali sumber daya alam. Akan tetapi pada kenyataannya persawahan di daerah tersebut tidak pernah cukup oleh air. Keadaan tersebut merupakan sebuah takdir yang benar-benar berasal dari Tuhan. Kemudian takdir lainnya yang harus dihadapi oleh sebagian masyarakat yang menggantungkan hidupnya pada tanah adalah saat sawah hanya dapat sedikit air dan sama sekali tidak dapat diolah dan ditanami kemudian tanah-tanah tersebut dipertemukan dengan hasil tebangan-tebangan kayu di mulut jubung dan lahirlah gamping. Akan tetapi iroonisnya kembali pekerjaan ini sama sekali tidak membawa perubahan besar dalam kehidupan masyarakat dan belum memberi kecukupan kepada masyarakat. Mendapati keinginan yang ditolak oleh beberapa pihak merupakan salah satu ciri yaitu ironi, seperti dalam kutipan:

(17) Kalau melihat mata Ulid, niscaya akan tahu betapa ia menunggu jawaban dari pertanyaan itu. Matanya tak sabar, seperti mata bocah yang menunggu baju baru yang dibuka dari bungkusnya. Tapi pundaknya telah ditarik paksa menjauh oleh emaknya "sini, nanti mata kamu kena debu gamping, perih" (Ikhwan, 2016:33).

Pada data (17) terdapat sebuah keinginan yang diutarakan oleh tokoh Ulid, namun kemudian dipatahkan oleh ibunya meskipun dengan alasan kesehatan untuk tokoh Ulid sendiri. Ulid yang begitu bersemangat menyaksikan bapaknya yang sedang membakar gamping dan berkeinginan untuk terus menyaksikan kemudian datang emaknya dan menyuruhnya untuk tidak dekat dengan lokasi pembakaran gamping tersebut agar mata Ulid tidak terkena debu gamping, karena debu dapat menyebabkan mata seseorang menjadi perih.

\section{Pembahasan}

Berdasarkan hasil analisis data diperoleh data-data yang menunjukkan prilakuprilaku postmodernisme yaitu aspek budaya yang terdapat dalam novel Ulid karya Mahfud Ikhwan yang berupa ekletisisme, parodi, pastiche, ironi dan camp. Novel Ulid karya Mahfud Ikhwan yang bertemakan perjuangan anak desa untuk mendapatkan pendidikan, kemudian mengajarkan banyak hal mengenai kehidupan misalnya kegigihan dalam mencari ilmu pengetahuan, perlakuan-perlakuan yang patut dalam 
Jurnal Onoma: Pendidikan, Bahasa dan Sastra PBSI FKIP Universitas Cokroaminoto Palopo Volume 7 Nomor 1 Tahun 2021
ISSN 2443-3667 (print)

ISSN 2715-4564 (online)

berkeluarga dan bermasyarakat serta sikap yang tak pantang menyerah. Beberapa hal tersebut akan diinterpretasikan sebagai berikut:

\section{Ekletisisme}

Novel Ulid karya Mahfud Ikhwan terdapat 3 data yang mengungkapkan keberadaan suatu bentuk aspek postmodernisme yaitu ekletisisme dengan berbagai bentuk perpaduan yang dilakukan oleh tokoh dalam novel. Pengadopsian prilaku atau penggunaan benda dari negara lain menjadi ciri utama dari ekletisisme (Faisal, 2013:405). Seperti yang telah dikemukakan sebelumnya bahwa penggunaan benda menjadi ciri utama dari bentuk ekletisisme.

Tidak hanya dalam penggunaan benda, melainkan bahasa, makanan maupun aktivitas-aktivitas yang dilakukan oleh masyarakat sering mencampuradukkan suatu kebudayaan sendiri dan kebudayaan asing, hal ini telah menjadi umum dilakukan oleh tokoh-tokoh dalam novel yang bergaya modern. Sikap dan tingkah laku ekletisisme ditunjukkan dalam data $(1,2,3)$ seperti kegiatan menggunakan bahasa dari luar negeri, menggunakan benda-benda yang berasal dari luar negeri, mengkomsumsi makanan yang berasal dari luar negeri, dan aktivitas-aktivitas yang dilakukan.

\section{Parodi}

Parodi yaitu sebuah komposisi dalam prosa atau puisi yang memiliki kecenderungan pengungkapan yang diimitasi sedemikian rupa untuk membuatnya tanpak absurd untuk menghasilkan efek-efek kelucuan. (Hartono, 2008:64). Dalam sebuah novel banyak mengungkapkan perasaan yang kadang tidak ingin diungkapkan secara gamblang, sehingga diperlukan kata-kata yang dapat mewakili pengungkapan tersebut dan disampaikan dengan rasa humor. Novel-novel yang bergaya humor telah banyak di masa sekarang.

Bentuk parodi dalam novel Ulid karya Mahfud Ikhwan berjumlah 7 data yang diuraikan dalam data $(4,5,6,7,8,9,10)$ yang tergolong dalam bentuk pendramatisasian suatu kejadian yang berasal dari perasaan manusia yang mengandung humor untuk menjelaskan sesuatu kepada seseorang seperti perasaan tidak nyaman terhadap sesuatu, perasaan puas, perasaan senang, dan perasaan tidak bersemangat.

\section{Pastiche}

Pastiche adalah sesuatu hal yang merujuk pada teks-teks masa lalu kemudian mengangkat dan mengapresiasikannya menjadi suatu kebiasaan yang dialami oleh tokoh pada masa sekarang (Hatija, 2018:85), selain itu melakukan peniruan terhadap sesuatu yang pernah dilakukan pada masa lalu kemudian dilakukan kembali pada masa sekarang namun dengan versi yang berbeda, dalam hal ini seperti sebuah aktivitas maupun sebuah pengungkapan. Ketika suatu novel memiliki alur campuran, sesuatu yang lalu kemudian akan sering muncul kembali dan akan dibahas pada masa sekarang meskipun kadang dengan versi yang berbeda ataupun hal yang telah lalu baru diapresiasi pada masa sekarang.

Pastiche dalam novel Ulid karya Mahfud Ikhwan dapat digambarkan dengan adanya suatu bentuk teks atau verbal yang menggambarkan adanya pengungkapan mimpi-mimpi atau angan-angan terjadi sesuatu hal yang diinginkan atau yang diharapkan terjadi pada masa depan. Bentuk Pastiche dalam novel Ulid karya Mahfud 
Jurnal Onoma: Pendidikan, Bahasa dan Sastra PBSI FKIP Universitas Cokroaminoto Palopo Volume 7 Nomor 1 Tahun 2021
ISSN 2443-3667 (print)

ISSN 2715-4564 (online)

Ikhwan berjumlah 4 data yang diuraikan dalam data $(11,12,13,14)$ yang meliputi hal-hal yang mengimitasi sesuatu yang dilihat sebelumnya, menyangkut angan-angan atau mimpi-mimpi yang diharapkan, menyangkut gambaran-gambaran aktivitas yang terjadi di masa lalu kemudian diapresiasikan pada masa sekarang, kemudian teksteks yang memberi pengetahuan kepada pembaca tentang apa yang telah terjadi di masa lalu.

\section{Ironi}

Ironi merupakan suatu kejadian yang bertentangan dengan keinginan atau harapan akan tetapi telah menjadi suratan takdir atau ketetapan dari yang maha kuasa. Tidak hanya dalam segi sifat atau perlakuan yang kadang berbeda harapan dan kenyataannya, melainkan dapat terjadi pula pada keadaan-keadaan alamiah seperti bencana alam. Tentu saja hal-hal tersebut merupakan sebuah kejadian yang tidak sesuai dengan harapan.

Ketentuan Tuhan yang maha Esa menjadi bagian penentu pada keadaan alam dan manusia (Hatija, 2018:66). Ketentuan Tuhan yang dimaksud dalam aspek ini adalah ketentuan yang tidak sesuai dengan harapan atau keinginan disebut ironi. Dalam hal ini bentuk dari ironi yang berkaitan dengan alam yaitu kejadian bencana alam yang terjadi, tentu tidak ada yang mengharapkan bencana itu datang akan tetapi telah menjadi takdir Tuhan.

Bentuk ironi dalam novel Ulid karya mahfud Ikhwan berjumlah 3 data yang diuraikan dalam data $(15,16,17)$ yang meliputi keinginan-keinginan yang tidak terkabulkan atau ditolak, kekecewaan yang terjadi, perasaan-perasaan yang tidak idiinginkan terjadi seperti perasaan malu dan perasaan tidak bersemangat, keputusasaan, hal-hal yang terjadi secara tiba-tiba tanpa disangka-sangka namun bertentangan dengan harapan, dan memberikan sebuah pengetahuan kepada pembaca mengenai apa yang telah difikirkkan atau direncanakan belum tentu sesuai dengan kenyataan yang terjadi.

\section{Simpulan}

Aspek budaya yang terdapat dalam novel Ulid karya Makhfud Ikhwan adalah bentuk ekletisisme yang terdapat dalam novel Ulid karya Mahfud Ikhwan menggambarkan beberapa bentuk ekletisisme dapat yang ditemukan dalam beragam kategori yaitu penggunaan benda, bahasa, dan istilah-istilah bahasa asing yang dipadukan dengan bahasa setempat, serta makanan-makanan yang dikomsumsi. Aspek selanjutnya adalah bentuk aktivitas tokoh yang menunjukkan keberadaan aspek parodi dalam novel Ulid karya Mahfud Ikhwan ditemukan dalam berbagai situasi seperti dialog yang mencerminkan rasa tidak nyaman, kepuasan, perasaan senang, perasaan putus asa yang dialami oleh tokoh.

Salah satu bentuk situasi yang menggambarkan adanya bentuk pastiche dalam novel Ulid karya Mahfud Ikhwan adalah ungkapan yang menyatakan adanya peniruan terhadap apa yang pernah dilakukannya di masa lalu kemudian melakukan hal serupa pada masa sekarang. Adapun bentuk lainnya yaitu meniru apa yang telah dilihatnya atau pengimitasian, Mahfud Ikhwan juga menunjukkan keberadaan pastiche dalam bentuk memberi pengetahuan kepada pembaca tentang apa yang sering dilakukannya di masa lalu. Bentuk-bentuk ironi dalam novel Ulid karya Mahfud 
Ikhwan berkaitan dengan keinginan-keinginan yang ditolak, kekecewaan terhadap sesuatu, berhubungan dengan perasaan seperti perasaan malu, putus asa. Adapula yang memberikan pengajaran bahwa tidak semua yang kita pikirkan atau rencanakan dapat terlaksana dengan lancar selalu ada hal-hal tidak terduga yang mengganggu kelancaran rencana tersebut.

Ada beberapa hal yang berkaitan dengan camp dalam novel Ulid karya Mahfud Ikhwan yakni menyangkut pola sikap yang berprilaku tidak sesuai dengan apa yang ditampilkan, perumpamaan-perumpamaan yang mewakili suatu ungkapan lainnya baik dalam segi sikap atau penampilan. Misalnya dalam ungkapan "pekerjaan raksasa" yang berarti pekerjaan besar.

\section{Daftar Pustaka}

Faisal, Radfan. 2013. Postmodernisme pada Novel Maryamah Karpov Karya Andrea Hirata. Jurnal Artikulasi: Jawa Pos Radar Bromo, (7) 1: 86-95.

Fitriana, D. N. 2017. Identitas Budaya dalam Novel Kembar Keempat Karya Sekar Ayu Asmara: Kajian Postmodernisme. Academica Journal of Multidsciplinary Studies, (1) 1: 81-93.

Gudono, 2009. Teori Organisasi, Seri Bacaan Pascasarjana, Pensil. Yogyakarta.

Hartono. 2008. Karakteristik postmo dalam Kumpulan cerpen Mereka Bilang Saya Monyet! Karya Djenar Maesa Ayu. Jurnal Penelitian Bahasa, Sastra, dan pengajarannya. Jurnal Litera: Fakultas Bahasa dan Seni Universitas Negeri Yogyakarta.

Hatija. 2018. Representasi Postmodern dalam Novel Supernova Edisi Petir Karya Dee Lestari: Tinjauan Sosiologi Postmodernisme Jean Francois Lyotard. Skripsi. Program studi Bahasa dan Sastra Indonesia. Fakultas Bahasa dan Sastra Indonesia: Universitas Negeri Makassar.

Ikhwan, Mahfud. 2016. Kontribusi yang bagus bagi Sastra Indonesia "Ulid Sebuah Novel". Yogyakarta: PT Benteng Pustaka.

Lubis, Akhyar Yusuf. 2014. Postmodernisme: Teori dan Metode. Jakarta: RajaGrafindo Persada.

Maksum, Ali. 2008, Pengantar Filsafat, Dari Masa Klasik Hingga Postmodernisme. Yogyakarta: Ar-Ruzz Media.

Nurgiyantoro, Burhan. 2007. Teori Pengkajian Fiksi. Yogyakarta: Gajah Mada.

Piliang, Yasraf Amir. 2003. Hipersemiotika Tafsir Kultural Studes Atas "Matinya Makna". Bandung: Jalasutra.

Prihantono. 2018. Analisis Stilistika Seno Gumira Ajidarma dalam Cerpen Rembulan dalam Capucino: Kajian Postmodernisme Jean Francois Lyotard. Totobuang Jurnal Ilmiah Kebahasaan dan Kesastraan, (6) 1:

Priyatni, Endah Tri. 2012. Membaca Sastra dengan Ancangan Literasi Kritis. Jakarta: Bumi Aksara.

Rengganis, 2017. Sastra idealis versus industry kreatif: studi kasus Film Nay sebagai bentuk filmisasi novel nayla karya djenar Maesa Ayu. Jurnal Basastra Indonesia serta pengajarannya, (3) 1. 33-45. 
Jurnal Onoma: Pendidikan, Bahasa dan Sastra PBSI FKIP Universitas Cokroaminoto Palopo

Volume 7 Nomor 1 Tahun 2021
ISSN 2443-3667 (print)

ISSN 2715-4564 (online)

Sarup, Madan. 2007. Posstrukturalisme dan Postmodernisme: Sebuah Pengantar Kritis. Diterjemahkan oleh Medhy Aginta Hidayat. Yogyakarta: Jendela.

Sari, H \& Maming, R. 2019. Analisis Nilai Moral dalam Teks Ma'parapa Prosesi Rampanan Kapa Di Tana Toraja. Jurnal Semantik, (8) 2: 1-9.

Sari, H. dkk. 2020. The Function of the Educational Value in the Ma'parapa (Silence) Text in the Process of the Rampanan Kapa' (Wedding Ceremony). Jurnal Masyarakat, Kebudayaan dan Politik, (33) 3: 309-320. 